\title{
Design of the expert system to analyze disease in Plant Teak using Forward Chaining
}

\author{
Poningsih $^{1}$, Solikhun ${ }^{2}$, Iswar Ahmad ${ }^{3}$ \\ Teknik Informatika, ${ }^{I}$ AMIK \& STIKOM Tunas Bangsa Pematangsiantar \\ Pematangsiantar, North Sumatra, Indonesia
}

poningsih@amiktunasbangsa.ac.id ${ }^{1 *}$, solikhun@amiktunasbangsa.ac.id ${ }^{2}$, iswar@yahoo.com ${ }^{3}$

ARTICLE INFO

Article history:

Received : 05/10/2017

Revised : 05/30/2017

Accepted : 06/03/2017

Keywords:

Expert system;

Forward Chaining;

Plant teak;

\section{AB STR ACT}

Teak is one kind of plant that is already widely known and developed by the wider community in the form of plantations and community forests. This is because until now Teak wood is a commodity of luxury, high quality, the price is expensive, and high economic value. Expert systems are a part of the method sciences artificial intelligence to make an application program disease diagnosis teak computerized seek to replace and mimic the reasoning process of an expert or experts in solving the problem specification that can be said to be a duplicate from an expert because science knowledge is stored inside a database Expert System for the diagnosis of disease teak using forward chaining method aims to explore the characteristics shown in the form of questions in order to diagnose the disease teak with web-based software. Device keel expert system can recognize the disease after consulting identity by answering some of the questions presented by the application of expert systems and can infer some kind of disease in plants teak. Data disease known customize rules (rules) are made to match the characteristics of teak disease and provide treatment solutions.

Copyright @ 2017 International Journal of Artificial Intelegence Research. All rights reserved.

\section{Introduction}

Teak is a commodity of wood luxury, high quality, the price is expensive, and high economic value. Teak wood can be used as a base for housing construction, bridge construction, plywood, chassis frames, doors, windows, carving crafts of high artistic value also for furniture. In Indonesia, Teak is one plant that is able to contribute to the supply of wood raw material [1]. Excess Teak lies not only in the quality of wood which was very nice and very high economic value but also because of the properties of the silvicultural generally been mastered [2]. Teak wood is durable and strong. However, there are problems that hamper the process of the teak cultivation. There are various problems that arise in the process of cultivating teak, for example, the process of obtaining seeds of superior quality, the wrong way of planting, breeding, and the most common is the problem of pests and diseases [3]. Pest and disease problems are very disturbing pstemuctivity of teak farmers , because it can lead to decreased quality of pstemuction even the worst can lead to crop failure [4]. Consultation to someone who has expertise in certain subject in solving a problem is the right choice in order to get answers, advice, solutions, best decision or conclusion [5]. Answer an expert on a consultancy course very trustworthy or accountable and can affect the quality and the quality of the result of a problem, this is because an expert is always dominated to the 
plane he learned based on science and experience [6]. In this case the role of an expert is very reliable for determine the type of pests and diseases and give examples of countermeasures in order to get the best solution [7]. Similarly, if found any kind of pests and new diseases in plants, then an expert should do some research in order to obtain the particulars of pests or diseases new and as soon as possible socialization to farmers or farmer groups about the types of pests and diseases of new and how to handle [8]. However, there are constraints facing farmers plant teak. One is, the limitations to consult to an expert [9]. What if want to ask an expert about what caused crop failures and others, and the additional costs to be incurred when you want to consult with the experts [10]. This research explains how the methodology used to solve research problems [11]. The purpose of this study was to analyze the disease in teak plants so that it can find a solution for the problematic of teak becaused not all mobile workers know about pest control [12].

\section{Methods}

Research conducted at the place of teak plantations in Pasaman, where the plantations are privately owned teak plantations and also many teak plants are attacked by pests and diseases [13]. Research data collection techniques using direct analysis techniques in the field and accompanied by expert interviews method / field workers on the issues of disease and pest what and how the situation encountered in the field [14]. Information displayed on the system includes data diseases / pests that have identified the symptoms and solutions. In this menu the user can analyze the plant in question [15]. Having followed all the processes that are expected by the system will display the information of users, types of diseases / pests that attack, and solutions to overcome the disease / pest on plants teak [16].

\section{Result}

The characteristics of the disease that can be identified on a teak plantation consists of three aspects, namely [17] :

1. Physical Symptoms

2. Time Attack

3. Age Plants Attacked

Thus, it can be determined the characteristics of the table or tables identifying disease symptoms of the disease that is seen as in the following table [18]:

Table I Data Pest / Disease and Characteristics

\begin{tabular}{|c|c|c|c|c|}
\hline No & types of pests & Physical symptoms & time Attack & $\begin{array}{l}\text { Age Plants } \\
\text { Attacked }\end{array}$ \\
\hline 1 & Teak caterpillar pests & Perforated leaf & Nov-jan & Mature teak \\
\hline 2 & Uretpests & $\begin{array}{l}\text { Damaged roots and plants } \\
\text { wilt }\end{array}$ & February-april & Seed field \\
\hline 3 & Red mite pests / akarina & Pale yellow leaves & June-august & Seedling \\
\hline 4 & $\begin{array}{l}\text { White Mite pests / lice } \\
\text { wax }\end{array}$ & Curly leaf shoots & Any time & Mature teak \\
\hline 5 & White fliesPests & $\begin{array}{l}\text { Wilted leaves and Perforated } \\
\text { stem }\end{array}$ & Any time & Seedling \\
\hline 6 & Wilt disease & Wilted leaves and sandbar & August-february & Seedling \\
\hline 7 & Termites Pests & Perforated stem & Any time & Mature teak \\
\hline 8 & Shaky-shaky & There is liang auger in stem & March april & Mature teak \\
\hline 9 & Borer shoot pest & Nursery shoots wither & Any time & Seed field \\
\hline 10 & White Mite pests & Leaf curl & $\begin{array}{l}\text { February to } \\
\text { september }\end{array}$ & Mature teak \\
\hline 11 & $\begin{array}{c}\text { White butterflyPests / } \\
\text { diver }\end{array}$ & Fall & $\begin{array}{l}\text { February to } \\
\text { september }\end{array}$ & Mature teak \\
\hline 12 & Powder wet beetle pest & $\begin{array}{l}\text { Skin stem become dark } \\
\text { chocolate }\end{array}$ & Any time & Mature teak \\
\hline 13 & Bacterial wilt disease & $\begin{array}{c}\text { Withered leaves, scrolling } \\
\text { and dries }\end{array}$ & Any time & $\begin{array}{l}\text { Seed field / } \\
\text { Mature teak }\end{array}$ \\
\hline 14 & Inger-inger & Swelling in stem & Any time & Mature teak \\
\hline
\end{tabular}

As for the solution or way of controlling diseases / pests that attack plants teak above are: 
Table II

\begin{tabular}{|c|c|c|}
\hline No & Code & Identification \\
\hline 1 & $\mathrm{C} 01$ & Theplant's age that attacked is mature teak \\
\hline 2 & $\mathrm{CO} 2$ & Theplant's age that attacked is Seed Field \\
\hline 3 & $\mathrm{CO3}$ & Theplant's age that attacked is Seed \\
\hline 4 & $\mathrm{CO4}$ & Perforated leaf \\
\hline 5 & $\mathrm{CO5}$ & Damaged roots \\
\hline 6 & $\mathrm{C} 06$ & plants wilt \\
\hline 7 & $\mathrm{CO} 7$ & Pale Yellow Leaves \\
\hline 8 & $\mathrm{COS}$ & Curly leaf shoots \\
\hline 9 & $\mathrm{CO9}$ & Withered leaves \\
\hline 10 & $\mathrm{C} 10$ & Perforated stem \\
\hline 11 & $\mathrm{C} 11$ & Sandbar leaves \\
\hline 12 & $\mathrm{C} 12$ & There is liang auger in stem \\
\hline 13 & C13 & Nursery shoots wither \\
\hline 14 & $\mathrm{C} 14$ & leaf curl \\
\hline 15 & C15 & Fall \\
\hline 16 & C16 & Skin stem become dark chocolate \\
\hline 17 & $\mathrm{C} 17$ & Scrolling leaves \\
\hline 18 & C18 & Withered leaves and Dries \\
\hline 19 & C19 & There is Swelling in stem \\
\hline 20 & $\mathrm{C} 20$ & Occurred Between the November-January \\
\hline 21 & $\mathrm{C} 21$ & Occurred Between the February - April \\
\hline 22 & $\mathrm{C} 22$ & Occurred Between the June - August \\
\hline 23 & $\mathrm{C} 23$ & Occurred Between the August - February \\
\hline 24 & $\mathrm{C} 24$ & Occurs Between the March-April \\
\hline 25 & $\mathrm{C} 25$ & Occurred Between the February - September \\
\hline
\end{tabular}

As in this case, there are 27 rules needed to find a conclusion to be made through the questions that correspond with the identification data. From the identification data that has been obtained as shown in Table 6 above, the question can be classified by age identification variable plants are attacked first. Because the plants age data are common traits, which is where one of the plants age certainly is True that later will facilitate reasoning to determine identification which subsequently came to the conclusion sought. If the system already knows the age of teak plants are attacked, it will continue with questions about physical symptoms and the time of the attack. The rules are reflected in the hierarchy of the following Rules :

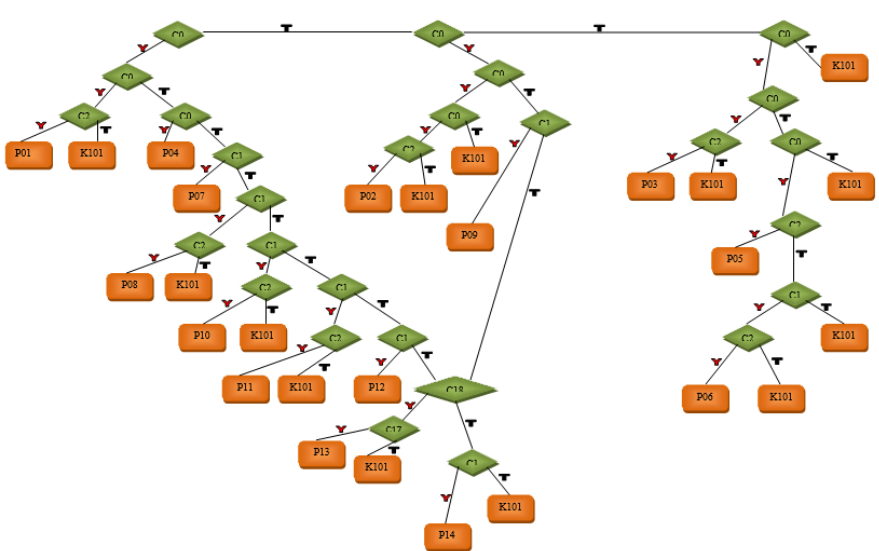

Table III Table Description

\begin{tabular}{ll}
\hline Structur & \\
\hline C01 & Theplant's age that attacked is mature teak \\
\hline C02 & Theplant's age that attacked is Seed Field \\
\hline C03 & Theplant's age that attacked is Seed \\
\hline 004 & Perforated leaf \\
\hline C05 & Damaged roots \\
\hline C06 & plants wilt \\
\hline C07 & Pale Yellow Leaves \\
\hline 08 & Curly leaf shoots \\
\hline C09 & Withered leaves \\
\hline C10 & Perforated stem \\
\hline C11 & Sandbar leaves \\
\hline C13 & There is liang auger in stem \\
\hline C14 & Nursery shoots wither \\
\hline C15 & leaf curl \\
\hline C16 & Fall \\
\hline C17 & Skin stem become dark chocolate \\
\hline C18 & Scrolling leaves \\
\hline C19 & Withered leaves and Dries \\
\hline C20 & There is Swelling in stem \\
\hline C21 & Occurred Between the November-January \\
\hline C22 & Occurred Between the February - April \\
\hline C23 & Occurred Between the June - August \\
\hline C24 & Occurred Between the August - February \\
\hline C25 & Occurs Between the March-April \\
\hline C26 & Occurred Between the February - September \\
\hline C27 & Occurred Between the February - September \\
\hline P01 & perforated stem \\
\hline P02 & Teak caterpillar pests \\
\hline P03 & Uretrests \\
\hline P04 & Red mite pests / akarina \\
\hline 005 & White Mite pests / lice wax \\
\hline & White flies Pests \\
\hline
\end{tabular}


Improvement of infant neonate infarction condition if lag time between attack and handling still less than three hours and immediately opening the blockage, then can still be expected optimal recovery in patient. In addition to this, efforts to reduce risk factors for the occurrence of infarct among other things, by maintaining the stability of blood pressure, maintaining the balance of weight badaa, as well as the stability of blood sugar and cholesterol levels by improving diet and not smoking.

\section{Conclusion}

Based on the design that has been created, it can be concluded that : it is necessary to create an application program that can be used to detect disease in plant teak. From the application program that created later are able to provide solutions to overcome problems or diseases that attack plants teak. To get a more varied this research may be further developed by researching new diseases that arise with the characteristics or symptoms that mark the disease. It is very important to investigate new symptoms that arise in disease of teak plant that already exists. Several types of pests may become resistant to a particular pesticide, therefore needs to be done towards innovation and new solutions to pest arising. Necessary new innovations for the pest handling so that more effective.

\section{References}

[1] Sumijan, Agus Perdana Windarto, Abulwafa Muhammad and Budiharjo, 2016, Implementation of Neural Networks in Predicting theUnderstanding Level of Students Subject, International Journal of Software Engineering and Its Applications Vol. 10, No. 10 (2016), pp. 189-204 http://dx.doi.org/10.14257/ijseia.2016. 10.10 .18
[2] H. Chiroma, S. Abdulkareem, A. I. Abubakar and T. Herawan, "Kernel functions for the support vector machine: comparing performances on crude oil price data", In Recent Advances on Soft Computing and Data Mining, Springer International Publishing, (2014), pp. 273-281.

[3] R. F. Hakim, E. N. Sari and T. Herawan, "Soft Solution of Soft Set Theory for Recommendation in Decision Making", In Recent Advances on Soft Computing and Data Mining, Springer International Publishing, (2014), pp. 313-324.

[4] A. Lasisi, R. Ghazali and T. Herawan, "Comparative performance analysis of negative selection algorithm with immune and classification algorithms", In Recent Advances on Soft Computing and Data Mining, Springer International Publishing, pp. $441-452$.

[5] B. Handaga, T. Herawan and M. M. Deris, "FSSC: An Algorithm for Classifying Numerical Data Using Fuzzy Soft Set Theory", International Journal of Fuzzy System Applications (IJFSA), vol. 2, no. 4, (2012), pp. 2946.

[6] T. Herawan, Z. Abdullah, H. Chiroma, E. N. Sari, R. Ghazali and N. M. Nawi, "Cauchy criterion for the HenstockKurzweil integrability of fuzzy number-valued functions", In Advances in Computing, Communications and Informatics (ICACCI, 2014 International Conference, IEEE, pp. 1329-1333.

[7] Ma, X., Qin, H., Sulaiman, N., Herawan, T. and Abawajy, J.H., 2014. The parameter reduction of the interval-valued fuzzy soft sets and its related algorithms.IEEE Transactions on Fuzzy Systems, 22(1), pp.57-71.

[8] Yanto, I.T.R., Ismail, M.A. and Herawan, T., 2016. A modified Fuzzy k-Partition based on indiscernibility 
relation for categorical data clustering. Engineering Applications of Artificial Intelligence, 53, pp.41 -52.

[9] Abubakar, A.I., Zeki, A., Chiroma, H. and Herawan, T., 2014. Investigating Rendering Speed and Download Rate of Three-Dimension (3D) Mobile Map Intended for Navigation Aid Using Genetic Algorithm. In Recent Advances on Soft Computing and Data Mining (pp. 261 -271).Springer International Publishing.

[10] Qin, H., Ma, X., Herawan, T. and Zain, J.M., 2012, May. An improved genetic clustering algorithm for categorical data.In Pacific-Asia Conference on Knowledge Discovery and Data Mining (pp. 100-111).Springer Berlin Heidelberg.

[11] Shah, H., Ghazali, R., Nawi, N.M., Deris, M.M. and Herawan, T., 2013. Global artificial bee colonyLevenberqMarquardt (GABC-LM) algorithm for classification.International Journal of Applied Evolutionary Computation (IJAEC), 4(3), pp.58-74.

[12] Castaño, B., Moreno, Á .,Carbajo, M. and de Pedro, J., 2008. Artificial Intelligence and Bluetooth Techniques in a Multi-user M-learning Domain.IJCSA, 5(1), pp.1 -13.

[13] Mohammad Mohammadi and Shahram Jafari,2014, An expert system for recommending suitable ornamental fish addition to an aquarium based on aquarium condition, International Journal of advanced studies in Computer Science and Engineering IJASCSE, Volume 3, Issue 2.

[14] Raymond McLeod, Jr. Management Information Systems, Prentice-Hall International, Inc. 1998.

[15] Mahmood Houshmand and Mohammad Daneshvar Kakhki,2007,Presenting a Rule Based Loan Evaluation Expert System, International Conference on Information Technology (ITNG'07),07695-2776-0/07 \$20.00 @ 2007, IEEE.

[16] Sasikumar, M, S Ramani, S Muthu Raman, KSR Anjaneyulu, and R Chandrasekar. $2007 . \quad$ A PracticalIntstemuction to Rule Based Expert. New Delhi: Narosa Publishing House.

[17] Durnkin, John. 1994. Expert system design anddevelopment. New York: Macmillan Publishing Company.

[18] Liao, Shu-Hsien. 2005. "Expert system methodologies and applications - a decade review from 1995 to 2004." Elsevier 1-11 